Ursin, J. (2017). Tranforming Finnish Higher Education: Institutional Mergers and Conflicting Academic Identities.

Revista de Investigación Educativa, 35(2), 307-316

DOI: http://dx.doi.org/10.6018/rie.35.2.295831

\title{
Tranforming Finnish Higher Education: Institutional Mergers and Conflicting Academic Identities
}

\section{Cambiando la Eduación Superior Finlandesa:Transformación institucional e identidades académicas en conflicto}

\author{
Jani Ursin \\ *Finish Institute for Educational Research \\ Univesity of Jyväskylä. Finland
}

\begin{abstract}
As in many other European countries also Finnish higher education system has witnessed several reforms over the past decade many of which originate in efforts to make more competitive and affordable higher education system. The aim of this paper is to describe the changes and institutional mergers in particular that have taken place in Finnish higher education and explore what kind of academic identities are constructed amid changes in Finnish higher education. The paper shows that the mergers followed the objectives set by the Finnish Ministry of Education and Culture for the structural development of the higher education system and that the creation of a joint culture for merged institutions was important yet challenging. The paper also argues that due to these external changes in Finnish higher education there is a tendency to move from a traditional notion of an academic toward more hybrid and dynamic understanding of what it is being an academic in the 21st century.
\end{abstract}

Keywords: academic identity; Finland; higher education; merger.

Correspondencia: Jani Ursin 


\section{Resumen}

Como en muchos otros países europeos, también el sistema educativo superior finlandés ha sido testigo de diversas reformas durante la pasada década, muchas de las cuales se traducen en esfuerzos para hacer más competitivo y profundo el sistema educativo superior. El objetivo de este artículo es describir los cambios y transformaciones institucionales que en particular se han producido y explorar qué tipo de identidades académicas se construyen dentro de los cambios en la educación superior finlandesa. El estudio muestra que las transformaciones asumieron los objetivos dispuestos por el Ministerio de Educación y Cultura finlandés para el desarrollo estructural del sistema educativo superior y que la creación de una cultura articulada para las instituciones transformadas era importante, aunque representara un reto. El estudio también plantea que, debido a estos cambios externos, en la educación superior finlandesa existe una tendencia a desplazarse desde una noción tradicional de las materias hacia una comprensión más plural y dinámica sobre lo que es una materia (asignatura) en el siglo XXI.

Palabras clave: identidades acaémicas; Finlandia; Eduación Superior; transformación.

\section{Introduction}

Higher education systems are being transformed worldwide. The impetus for reconstructions typically stems from the needs of global competition in higher education. Structural reforms are inevitable not only due to the accelerating development of science and technology but also because traditional ways to organise research and education in higher education institutions must be reconsidered to improve the quality of education (Mok, 2005; Mathisen \& Pinheirio, 2016). National reforms are widely motivated by a global trend towards larger and more competitive units; and this is often accompanied with a striving for enhanced strategic networking between higher education institutions. In response to these developments universities are hoped, for example, to strengthen their profiles and strategies by institutional cooperation and mergers (Tirronen \& Nokkala, 2009; Melin, 2015). Through these measures universities are expected to enhance their research facilities, to improve their administration and management, and to attract qualified faculty members and students. Indeed, various slogans of neo-liberal ideologies for high quality, attractiveness and competitiveness are commonly wielded in policy discourses to promote the mergers. These macro-level changes in the policy, funding and governance of higher education have also impact on the micro-level of daily activities in academia, moulding how academics make sense of their work and their roles (Ylijoki \& Ursin, 2013).

In Finland, where traditionally higher education institutions have enjoyed a high degree of institutional autonomy despite being mainly funded by the nation state, the Government initiated a series of reforms from the mid-2000s onwards which were labelled as 'structural development of the Finnish higher education system'. This initiative drastically changed the perception and course of reforms in Finland. Until the mid-2000s the development of Finnish higher education system had focussed on expanding the system but now the attention shifted to strengthen, profiling and concentrating the operations into larger operational units. Overall, the goals for the reforms were to make Finnish higher education more responsive to the changes taking 
place globally. In practice, it was hoped that the reforms would, among other things, diversify the funding base of universities, provide better opportunities to compete for international research funding, increase cooperation with foreign (top class) universities as well as ensure the quality and effectiveness of university-based research and teaching activities.

The main reforms in Finnish higher education system over the past decade have been an introduction of a more performance-based salary structure in 2005 (Jauhiainen, Jauhiainen \& Laiho, 2009); the New Universities Act of 2010 devolved the university sector from government control and transformed civil-service employment relationships into contractual ones (Välimaa, 2012); institutional mergers have created four new universities since 2010 (Ursin, Aittola, Henderson \& Välimaa, 2010; Välimaa, Aittola \& Ursin, 2014); furthermore, a results-based funding formula was introduced in 2015. All of these reforms have promoted the implementation of neo-liberal and managerialist ideologies and practices into Finnish higher education (Rinne \& Jauhiainen 2012). There is some empirical evidence that as a consequence of these cumulative changes, Finnish academics are becoming polarised into different categories, consisting of those who benefit from the changes and those who do not, (Ylijoki \& Ursin, 2013, 2015).

The aim of this paper is first to describe the implementation of mergers of Finnish universities and second to explore what kind of academic identities are constructed amid the changes in Finnish academia. Finally, the paper makes some conclusions on the current state of Finnish higher education and academic life. In the next section I will describe the process of implementing university mergers in Finland.

\section{Mergers of Finnish Universities as a Response to Global Challenges}

Impetus [for a merger] came from the Finnish Ministry of Education when they introduced structural development of higher education but my personal opinion is that we were already in the point where a merger was inevitable (Male administrator).

As the quotation from a research interview above highlights mergers are often seen as a driving force for change in higher education institutions. The new alignments in research, education and innovation activities are expected to help respond to the global competition of university systems, particularly by revised knowledge production so as to serve better the needs of industry, business and regional stakeholders (Mok, 2005). Hence, the aims for mergers are multifaceted. One of the most common expected benefits from mergers is that by decreasing the number of institutions they would lower the financial costs of maintaining the higher education system. Great expectations are also set for added capacity to compete for international research funding. Similarly, mergers are hoped to help recruit the most gifted faculty members and students abroad by providing attractive academic environments to work and study. At the institutional level these internationally oriented aims are accompanied with needs to integrate management procedures and reduce administrative costs. Hence, mergers are intended to create optimal conditions for research and education (Aarrevaara, Dobson \& Elander, 2009). 
However, a university merger is a complicated and long-lasting process encompassing several aspects and phases (Mao et al. 2009). Previous studies have indicated that a successful merger of universities requires strong leadership especially in the implementation phase (e.g. Hay \& Fourie, 2002; Livio \& Tomperi, 2011), effective management of university (Kyvik, 2002; Eckel \& Kezar, 2003; Locke, 2007), and transparent communication among all relevant stakeholders (e.g. Hatton, 2002). On the whole, creating a new joint organisational culture is a challenging task in merger settings. Accordingly, discussions about the new institutional identity and sense of belonging are a necessary and integral part of a merger (Harman \& Harman, 2003; Calma \& Davies, 2015). Furthermore, mergers also have effect on the academic identities (Ylijoki \& Ursin, 2013, 2015).

The Finnish higher education system, which is based on the principles of welfare state ideology (free education, equality as a basic value) consists of two complementary sectors: universities and universities of applied sciences. At the beginning of the government-initiated structural development of Finnish higher education in 2006 there were over 46 higher education institutions. Currently (year 2017) there are 14 universities and 24 universities of applied sciences altogether with just over 300,000 students. The first three new universities through mergers were created in 2010: 1) Aalto University: Helsinki University of Technology + Helsinki School of Economics + the University of Art and Design Helsinki, 2) the University of Eastern Finland: the University of Joensuu + the University of Kuopio, 3) the University of Turku: Turku School of Economics + the University of Turku. There was also a fourth merger project (University Alliance Finland: Tampere University of Technology + the University of Tampere + the University of Jyväskylä) which remained a very loose alliance and never led to an actual merger.

In their study of the above-mentioned mergers Ursin, Aittola \& Välimaa (2010) found out that the aims of the different Finnish university mergers were interpreted quite uniformly. The objectives set by the Finnish Ministry of Education and Culture for the structural development of the higher education system were realised in the merging universities. These included striving for internationalisation, improvement of quality, increasing competitiveness, clarification of profiles, enhancing the activities so that it is possible to cut down overlapping teaching, standardise practices, and increase flexibility. However, the changes especially in educational activities seem to be realised and rooted gradually, especially because in many cases structural changes, such as financial and administrative rearrangements, precede the changes in education and teaching. Furthermore, the success of mergers ultimately depends on how the new possibilities and ways of doing things are adopted, to what extent new study programmes and joint teaching will be put into practice, how students can take advantage of the variety of possibilities, and how and to what extent administrative constraints will be removed to make studying more flexible within and beyond the merged universities. Open communication and well-functioning leadership had a central role in the implementation of a merger in the Finnish context. Additionally, the creation of a joint organisational culture was seen as an important and challenging task. Similar results have been found in in many international studies (see e.g. Hay \& Fourie, 2002; Kyvik, 2002; Harman \& Harman, 2003; Calvin \& Davies, 2015). 
The main challenges in Finnish mergers were connected to the sufficiency of resources, to dispelling prejudices, and to managing geographical distances between campuses by utilising the possibilities of information and communications technology (cf. Kyvik, 2002). At best the mergers were regarded to contribute to the establishment of new practices and to the creation of a joint culture giving rise to a strong "we-spirit". Furthermore, the merger ideally would entail rationalisation with regard to the use of resources, and offer broader possibilities for studying. In the Finnish context it seems, however, that the actual changes in education, teaching and learning are to be adopted quite slowly, although the structural framework will be changing more rapidly (Ursin, Aittola, Henderson \& Välimaa, 2010). This finding is congruent with those of several international studies, since systemic transformations in education are usually fairly slow processes (see Mao, Du \& Lia, 2009).

Ursin, Aittola \& Välimaa (2010) conclude that although the results indicate that the merger processes have largely been similar as to their starting points and aims in different universities, the issues and implications of the merger were primarily connected to the institutions' own culture and history. In consequence, the unique features and strengths of each university should be taken into account as a basis of a merger. The previous (e.g. Dahl Norgård \& Skodvin, 2002) studies have highlighted the fact that creating a joint culture is a challenging task. This was also true in the Finnish context. The creation of a collective culture was found to be a very important and challenging factor. It seemed that the central role of well-functioning leadership and open communication in establishing a joint culture. It is therefore important to pay more attention to the creation of a "we-spirit" as well as to openness and transparency at all stages of a merger.

In the next section I will shift focus on how Finnish academics perceive their identities amid various structural changes and introduction of more neoliberal and managerialist principles, practices and procedures into Finnish higher education.

\section{Conflicting Narratives of Finnish Academic Identities}

We got the maximum 7 points in an international [research] assessment, and it said that in these fields we're the trendsetter, globally-we're the ones who set the direction for others. (...) This environment is really good from our point of view. As this has been a priority area, we've received special support from the university management for developing infrastructure, and for some posts as well. In fact, there's really nothing to complain about (male professor).

Overall I'm annoyed that business principles have been introduced into the university. (...)There are ethical questions involved, so I don't want this. (...) I mean, what's happening in the university system nationally, how things are, and also what's happening inside the university. All this development, in my opinion, is heading in the wrong direction. I think we need a Humboldtian university (female associate professor).

These two quotations from research interviews illustrate how differently Finnish academics see the same changes, even in the same university or department. Ylijoki and 
Ursin $(2013,2015)$ have, indeed, identified conflicting narratives of Finnish academic identities which represent both regressive and progressive storylines. In the regressive storyline changes are perceived negatively as reflecting the deterioration of one's work context and of one's standing in academia. In the progressive storyline changes are described positively mirroring improvement and progress. The narratives of resistance, loss, work overload, job insecurity and cynical bystander represent regressive storyline of academic life and the narratives of success, mobility and change agency exemplify the progressive storyline.

In the narrative of resistance the changes in higher education are forcefully opposed for moral and ethical reasons as these changes often associate with managerialist and neo-liberal ideologies. The form of academic identity embedded in this narrative is that of critic and rebel. Academics make sense of their work through a lens of negativity; all the changes are considered to be impairment of academic work and thus something to be demoed. The narrative of loss follows the plot structure of a tragedy. The line it takes is that external changes to higher education have had a serious damaging effect on the nature of academic work. This academic identity is one of vulnerability and defencelessness. The academic has no capacity for fight against the changes imposed from above; identity construction is characterised by submission to the inevitable. The narrative of administrative work overload portrays academic work as involving an ever increasing administrative amount of work, due to the managerialist regulation and governing mechanisms. These are perceived as an otiose waste of time, preventing academics from fulfilling their real objective for teaching and research. The identity construction entailed in this narrative is that of an exhausted and overworked academic who is about to collapse under the weight of a constantly increasing administrative burden, and who yearns to devote her or himself to scholarly activities. The narrative of job insecurity tells of living and working in the shadow of potential unemployment. The narrative is characterised by the increasing precariousness of the fixed term employment culture. The academic identity embedded in this narrative is one of fragility combined with anxiety and distress over the future. Consequently, identity as an academic remains wavering, incorporating consideration and contemplation of alternatives and fall-back positions that unemployment may precipitate. The narrative of bystander interprets changes in higher education as remote and distant, occurring at the upper levels of the administrative hierarchy with little impact on one's daily work. The identity constructed in this narrative is one of an onlooker who is absorbed in his or her immediate tasks, and the university environment and its transformations do not feature within this confined field of attention. (Ylijoki \& Ursin, 2015.)

The narrative of change agency reflects a presumption that some academics act as the driving force behind of reforms. This narrative is typically associated with academics who have leadership roles as departmental heads or deans of a faculty. The academic identity rooted in this narrative is one of change agent and facilitator, combining soft managerialism with the role of a university teacher-researcher. The identity involves negotiating a balance between collegial and managerial stances and portrays an academic who understands the worries that transformation creates, but who is nonetheless persistent with implementing it. The narrative of mobility glorifies dynamism and flexibility as quintessential elements of academic life. Current changes 
in higher education are regarded as opportunities for engagement with other spheres of society and international mobility as well as providing the opportunities for exciting personal career paths. The academic identity embedded in this narrative is fluid and transitory; flexible enough to re-shape and take on the features of another professional identity. The narrative of success comprehends the reforms in an entirely positive light on account of their having yielded great benefits to one's own situation and one's academic profile. This narrative conveys the standing of an individual academic or field of study as having been strong from the outset, demonstrated by success. The academic identity associated with this narrative is characterised by self-confidence grounded in the conviction that one's academic standing both locally and in the international community is strong (Ylijoki \& Ursin, 2015).

Another example of clashing Finnish academic identities comes from the study of identity, agency (involves acting in work relationships, and also seeking to have influence on individual and shared work practices), and the emotions of academics by Ursin, Vähäsantanen, McAlpine and Hökkä (submitted). They found both balanced and tensioned forms of Finnish academic identities. Balanced identity included two narratives: narrative of confident teacher and narrative of passionate researcher. These balanced narratives included agentic efforts and rewarding, positively reinforcing experiences. Within these narratives, the academics recounted considerable opportunities to influence their work activities and, to a certain extent, to participate actively in the academic community. The narrative of confident teacher embodied a self-confident and knowledgeable academic identity with zeal for teaching as well as a strong and lucid identification of being a teacher. The narrative also represented strong agency allowing considerable freedom and possibility in deciding on what one was doing, the kinds of courses one could choose, and how one taught. The narrative of passionate researcher illustrated the identity of a knowledgeable and successful researcher. In the narrative of passionate researcher there were intrinsic motivations (such as a passion for research) and competence (in terms of being a skilful researcher) for doing research. The narrative of passionate researcher portrayed a strong agency in terms of being energetic and persistent in negotiating for more time for research.

The tensioned academic identity also included two narratives: narrative of insecure teacher and narrative of inadequate researcher both of which designated weak agency and included mainly expressions of adaptation, and there were few actual efforts to influence what were perceived as external matters. In this sense, accounts of an active form of agency were fairly rare in these narratives. The narrative of insecure teacher demonstrated a teacher who saw teaching as important and would readily like to be committed to it, but lacked, however, the means and competences to be an adept teacher. In the narrative of insecure teacher, agency was rather weak. There was a possibility to shape some aspects of the teaching practices; however, efforts to be agentive did not always work out as planned. The narrative of inadequate researcher mostly described academics' engagement in research, but also portrayed a researcher identity characterised by distress and feelings of inadequacy due to lacking competence to do research. Agency in the narrative of inadequate researcher is weak. One's vulnerability as a researcher was recognised, for example, when trying to successfully respond to the requirements posed by the university. (Ursin et al., submitted). 


\section{Conclusions}

The aim of the paper was to describe the changes and institutional mergers, in particular, that have taken place in Finnish higher education and explore what kind of academic identities are constructed amid changes in Finnish higher education. It seems that the implementation of a merger was a demanding task for universities and - at least in the implementation phase - the actual changes in research and teaching activities were rather modest despite the organisational changes (Ursin, Aittola, Henderson \& Välimaa, 2010). Naturally, the different histories and working environments of merged institutions created challenges in making a new shared culture. On the one hand fusions have forced higher education institutions in Finland to define their own individual profiles and invest more on rigorous strategic planning (Marttila \& Aittola, 2010). On the other hand these kinds of developments were labelled to be managerialist and not representing the values of traditional university thus creating struggles for academics of which 'master' to serve; the traditional Humboldtian one or the more entrepreneurial one.

Nonetheless, the findings of Finnish academic identities speak for the same tendency taking place in many European (and beyond) higher education systems; that is, to move from a traditional notion of an academic toward more hybrid and dynamic understanding of what it is being an academic in the 21st century. In this regard developments in Finland are in line with the several other studies revealing increasing fragmentation and heterogeneity within the academic profession (e.g. Anderson, 2008; Fanghanel, 2012; Gornall \& Salisbury, 2012; Henkel, 2005). Although the academic profession has always been differentiated into distinct cultures with specific notions of academic identity that relate to disciplinary fields and institutional settings (Becher, 1989), this diversity has become more pronounced due to the managerial and structural transformations in the university environment. The university is similarly perceived and interpreted in distinct ways through different narratives, ranging from idealised Humboldtian scholarly community to avarice exploitative employing institution.

It seems that the current state of affair of Finnish higher education and academic life is to live with various tensions which are created by different ways of understanding what higher education and academic lives are for. Various structural and organisational changes inevitable have impact on how academics perceive their roles and places in academia. In the Finnish context the institutional mergers, for example, have created larger units which have transformed the external conditions of doing academic work. This together with more managerialist movement, in turn, seems to call for a more hybrid and adaptable comprehension of academia as a work place and as a site to construct one's own career and professional identity. The main question, however, is whether this more dynamic academic environment will indeed enhance the quality of teaching and research. From the Finnish experience this is still too early to say but as, for example, Anthony Giddens has pointed out actions tend to have both intended and unintended consequences. 


\section{References}

Aarrevaara, T., Dobson, T. I., \& Elander, C. (2009). Brave new world: Higher education reform in Finland. Higher Education Management and Policy, 21(2), 1-18.

Anderson, G. (2008). Mapping academic resistance in the managerial university. Organization, 15(2), 251-70.

Becher, T. (1989). Academic Tribes and Territories. Buckingham: SRHE/Open University Press.

Calma, A., \& Davies, M. (2015). Studies in higher education 1976-2013: a retrospective using citation network analysis. Studies in Higher Education, 40(1), 4-21.

Dahl Norgård, J., \& Skodvin, O.-J. (2002). The importance of geography and culture in mergers: A Norwegian institutional case study. Higher Education, 44, 73-90.

Eckel, P., \& Kezar, A. (2003). Key strategies for making new institutional sense: Ingrediens to higher education transformation. Higher Education Policy, 16(1) 39-53.

Fanghanel, J. (2012). Being an academic. London: Routledge.

Gornall, L., \& Salisbury, J. (2012). 'Compulsive Working, 'Hyperprofessionality' and the Unseen Pleasures of Academic Work'. Higher Education Quarterly, 66, 135-154.

Harman, G., \& Harman, K. (2003). Institutional mergers in higher education: lessons from international experience. Tertiary Education and management, 9(1), 29-44

Hatton, E. J. (2002). Charles Sturt University: A case study in institutional amalgamation. Higher Education, 44(1), 5-27.

Hay, D., \& Fourie, M. (2002). Preparing the way for mergers in South African higher education and further education institutions: An investigation into staff perception. Higher Education, 44(1), 115-131.

Henkel, M. (2005). Academic Identity and Autonomy in a Changing Policy Environment. Higher Education, 48, 155-176.

Jauhiainen, A., Jauhiainen, A., \& Laiho, A. (2009). The Dilemmas of the Efficiency University Policy and the Everyday Life of University Teachers. Teaching in Higher Education, 14 (4), 417-428.

Kyvik, S. (2002). The merger of non-university colleges in Norway. Higher Education, $44,53-72$.

Livio, H.-L., \& Tomperi, H. (2011). Making Sense of Academic Leadership. Engage, 27, 1-4.

Locke, W. (2007). Higher education mergers: Integrating organizational cultures and developing appropriate management styles. Higher Education Quarterly, 61(1), 83-110.

Mao, Y., Du, Y., \& Lia, J. (2009). The effects of university mergers in China since 1990s. International Journal of Educational Management, 23(1), 19-33.

Marttila, L., \& Aittola, H. (2010). Yliopistojen yhteistyö ja fuusiot - ennakointia ja sopeutumista uuteen tilanteeseen. [Collaboration and fusions of universities preparation and adaptation to a new situation]. In H. Aittola \& L. Marttila (Eds.), RAKE - Yliopistojen rakenteellinen kehittäminen, akateemiset yhteisöt ja muutos. RAKEyhteishankkeen loppuraportti. [RAKE - The structural development of universities, academic communities and change.] Opetusministeriö. Opetusministeriön julkaisuja 2010:5, 93-95.

Mathisen, E.H. \& Pinheirio, R. (2016). The anatomy of a merger process in the greater Oslo Region. In R. Pinheiro, L. Geschwind \& T. Aarrevaara (Eds.), Mergers in Higher Education - The Experience from Northern Europe. Higher Education Dynamics, vol. 46. Springer, 91-106. 
Melin, G. (2015). University merger processes. In R. Pritchard, M. Klumpp \& U. Teichler (eds.), Diversity and Excellence in Higher Education - Can the Challenges be Reconciled (pp.31-52). Rotterdam: Sense Publishers:

Mok, K. (2005). Globalization and educational restructuring: University merging and changing governance in China. Higher Education, 50, 57-88.

Rinne, R., \& Jauhiainen, A. (2012). In the shifting sands of policy - University academics' and employees' views and experiences of Finland's new higher education policy, In S. Ahola \& D.M. Hoffman (eds.), Higher education research in Finland. Emerging structures and contemporary issues (pp. 89-110). Jyväskylä: Koulutuksen tutkimuslaitos

Sehoole, M.T.G. (2005). The politics of mergers in higher education in South Africa. Higher Education, 50(1), 159-179.

Skovdin, O.J. (1999). Mergers in higher education: Success or failure? Tertiary Education and Management, 5(1), 65-80.

Tirronen, J., \& Nokkala, T. (2009). Structural development of Finnish universities: achieving competitiveness and academic excellence. Higher Education Quarterly, 63(3), 219-236.

Ursin, J., Aittola, H., Henderson, C., \& Välimaa, J. (2010). Is education getting lost in university mergers? Tertiary Education and Management, 16(4), 327-340.

Ursin, J., Aittola, H. \& Välimaa, J. (2010). Kohti yhteisiä koulutusrakenteita. [Towards joint educational structures] In H. Aittola \& L. Marttila (eds.), RAKE - Yliopistojen rakenteellinen kehittäminen, akateemiset yhteisöt ja muutos. RAKE-yhteishankkeen loppuraportti. [RAKE - The structural development of universities, academic communities and change.] Opetusministeriö. Opetusministeriön julkaisuja 2010:5, 51-67.

Ursin, J., Vähäsantanen, K., McAlpine, L., \& Hökkä, P. Emotionally Loaded Identity and Agency in Finnish Academic Work. Submitted to Teaching in Higher Education.

Välimaa, J. (2012). The Corporatization of National Universities in Finland. In B. Pusser, K. Kempner, S. Marginson \& I. Ordorika (Eds.), Universities and the Public Sphere. Knowledge Creation and State Building in the Era of Globalization. (pp. 101-120). New York, London: Routledge.

Välimaa, J., Aittola, H., \& Ursin, J. (2014). University Mergers in Finland: Mediating Global Competition. New Directions for Higher Education, 168, 41-53.

Ylijoki, O-H., \& Ursin, J. (2013). The construction of academic identity in the changes of Finnish higher education. Studies in Higher Education, 38(8), 1135-1149.

Ylijoki, O.-H., \& Ursin, J. (2015). High-flyers and underdogs: The polarisation of Finnish academic identities. In L. Evans, \& J. Nixon (Eds.), Academic Identities in Higher Education: The Changing European Landscape (pp.187-202). Bloomsbury Academic.

Fecha de recepción: 31 de mayo de 2017

Fecha de revisión: 31 de mayo de 2017

Fecha de aceptación: 06 de junio de 2017 